\title{
Code-Switching in Online Synchronous Learning
}

\author{
Rinawati, N.K.A ${ }^{1 *}$, Putra, I.N.A.J ${ }^{2 *}$ \\ 1,2,3 Ganesha University of Education, Bali, Indonesia
}

\section{A R T I CLE I N F O}

Article history:

Received April 06, 2021

Revised April 07, 2021

Accepted June 17, 2021

Available online August 25, 2021

Kata Kunci:

Alih kode, Pembelajaran Sinkron

Online, WhatsApp

\section{Keywords:}

Code-switching, Online,

Synchronous Learning,

WhatsApp

DOI:

http://dx.doi.org/10.23887/jpbi.v9 i2.33585

\begin{abstract}
A B S T R A K
Wabah Covid-19 "memaksa” peralihan pengajaran dan pembelajaran tatap muka menjadi sepenuhnya online. Situasi ini juga mempengaruhi calon guru EFL dalam melakukan praktikum mengajar. Penelitian ini bertujuan untuk menganalisis calon guru EFL menggunakan alih kode dalam diskusi online melalui chat grup WhatsApp. Alih kode merupakan fitur bahasa populer yang biasa digunakan dalam komunikasi. Selanjutnya, tujuan penelitian dari penelitian ini adalah untuk mengidentifikasi jenis-jenis alih kode menurut teori Poplack dan juga untuk mengetahui fungsi alih kode berdasarkan teori Sert. Jenis penelitian ini yaitu kualitatif. Subyek penelitian ini adalah enam calon guru EFL dan siswanya. Data primer dikumpulkan dari diskusi online guru siswa melalui grup chat WhatsApp mereka kemudian diskusi tersebut ditranskrip menjadi transkrip. Teknik yang digunakan untuk menganalisis data yaitu analisis deskriptif kualitatif dan kuantitatif. Hasil penelitian pertama dalam hal jenis alih kode mengungkapkan bahwa semua peserta penelitian mempraktikkan alih kode dalam belajar mengajar online mereka melalui obrolan grup WhatsApp. Pembahasan tersebut memberikan tiga jenis alih kode berdasarkan teori Poplack, yaitu: tag-switching, inter-sentential switching, dan intra-sentential switching. Selanjutnya, tag-switching sering digunakan dalam diskusi online.
\end{abstract}

\section{A B S T R A C T}

The Covid-19 outbreak has "forced" face-to-face teaching and learning to be entirely online. This situation also affects prospective EFL teachers in conducting teaching practicums. This study aims to analyze prospective EFL teachers using code-switching in online discussions through WhatsApp group chats. Code-switching is a popular language feature commonly used in communication. Furthermore, this research aims to identify the types of code-switching according to Poplack's theory and to find out the code-switching function based on Sert's theory. This type of research is qualitative. The subjects of this study were six prospective EFL teachers and their students. Primary data was collected from online discussions of student teachers through their WhatsApp chat groups, and then the discussions were transcribed into transcripts. The technique used to analyze the data is descriptive qualitative and quantitative analysis. The first study's results in terms of types of code-switching revealed that all participants practiced code-switching in online teaching and learning through WhatsApp group chats. The discussion provides three types of code-switching based on Poplack's theory: tagswitching, inter-sentential switching, and intra-sentential switching. Furthermore, tag switching is often used in online discussions.

This is an open access article under the CC BY-SA license. Copyright $(C) 2021$ by Author. Published by Universitas Pendidikan Ganesha.

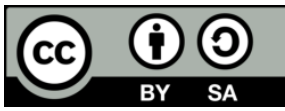

\section{INTRODUCTION}

Covid-19 has impacted all life sectors including the education field, which affected the teachinglearning process worldwide (Calvo et al., 2020; Sari et al., 2020). Covid-19 forced all students and teachers from elementary to higher education to change the traditional instruction of learning to fully online instruction (Adedoyin \& Soykan, 2020; Yu, 2021). Luckily, current global development has provided more opportunities in the advancement of technology and application for teachers in adopting online learning to assist conventional learning (Huang et al., 2011; Lage-Cala et al., 2020). Further, technology made the learning process simpler compared to traditional learning. It creates the opportunity for educators to move beyond the traditional face-toface classroom by mixing or blending this technology with traditional teaching and learning (Mershad \& Wakim, 2018; Ran \& Jinglu, 2020).

Online learning can be experienced through synchronous and asynchronous environments over internet access in different devices (Kassim \& Idris, 2018; Setiawan \& Ari Oka, 2020). Synchronous learning is characterized as a similar time setting with real-time learning, and it enables participants to react in the same session simultaneously, for instance online learning through video conferencing, live video, and live chat (Amiti, 2020; Kiernan, 2020; Rhim \& Han, 2020). Besides, asynchronous learning is characterized by its flexibility of time and place to access (Hogan \& Devi, 2019; Rhim \& Han, 2020). For instance, learning management systems 
(LMS), email, asynchronous online discussion, or direct messages (Al-Ajlan, 2015; Atmojo \& Nugroho, 2020). Moreover, in this case of the covid-19 outbreak, teachers are trying to find tools and techniques that will enable them to establish connections with and among students in addition to making all instructional materials accessible fully online.

Studies have shown that instant and text messaging technologies are used widely as media connections which can be effective in improving student learning when it is used to facilitate dialogic activities such as discussion forums and structured question-and-response, particularly in the context of language learning (Kim et al., 2021; Yuan \& Wu, 2020). When a learning activity is supported by mobile learning, learners have many opportunities to actively construct their knowledge and drive more interaction conducted via internet-mediated in a textual way instead of passively receiving information from a teacher (C.-H. Chen \& Tsai, 2021; Soleimani et al., 2014). In other words, mobile learning not only provides EFL learners easy-to-access multimedia information but also engages them in a spontaneous learning environment in which learners can decide where, what, and when to learn (Laksana et al., 2019; Zarkasi \& Taufik, 2019).

In language learning, the role of a teacher is very essential for ensuring students learn the target language appropriately (Y. Chen et al., 2019; López et al., 2021). It is in line with the goal in language learning is to make learners competent in using the language learned. Proficiency level in communication using English was indicated by the learner's capability to communicate both in written as well as spoken forms (Fakhruddin et al., 2019; Ika Febriandari, 2019). Unluckily, during the total closure in the education setting due to the covid-19 outbreak, all teaching and learning activities are done online thoroughly without physical interaction and utilized by technology. Therefore, the absence of social interaction in language learning during this shifted learning mode surely influences the learning instructions and how students and teachers communicate in the process of learning which leads to code-switching.

Code-switching is defined as the phenomenon of using more than one language in the same conversation or sentence by bilingual people (Ataş \& Sağın-Şimşek, 2021; Hsieh \& Tseng, 2017). Moreover, there were three types of code-switching, namely: tag-switching, inter-sentential code-switching, and intrasentential code-switching (Chau \& Lee, 2021; Gosselin \& Sabourin, 2021). Regarding Poplack's explanation, tag-switching is defined as the insertion of another language into the lingual unit of a sentence in a speech. Tagswitching mostly involves inserting a tag or a single word of the first language into a sentence that is uttered in the target language (Yacovone et al., 2021; Yaw et al., 2021). It could happen either to monolingual or bilingual people since the speakers only need to insert a random word from another language without violating the grammatical rules of the language (Andrade et al., 2014; Marcu, 2020). Tag-switching can be an exclamation or a tag that is not in the same base language as the entire sentence, for instance: "okay", "well", "I mean", "you know". And also an interjection in the form of a name or phrase that happens as a statement on its own and shows a spontaneous response or reaction (Sidiq et al., 2019).

Subsequently, inter-sentential switching refers to the switches that occur at a clausal or sentential level where speakers emphasize a certain point uttered in another language. It requires the speakers to have great fluency in both languages because a larger part of the utterance is supposed to follow the linguistics rules of both languages as compared to the minimal adjustment needed in tag-switching (Durani et al., 2012; Wu et al., 2017). Moreover, an inter-sentential switching also happens when there is a complete sentence in a foreign language uttered between two sentences in a base language and directly changed to the second language in the next sentence (Ataş \& Sağın-Şimşek, 2021; Chau \& Lee, 2021).

Additionally, intra-sentential switching is possibly the most complex type among the three types of code-switching based on Poplack's theory. In this type of code-switching, the speaker is trying to connect the switches with the utterance they are uttering and it occurs within the sentence and the switch links the two languages (Fernandez et al., 2019; Gosselin \& Sabourin, 2021). It also may appear in the beginning, in the middle, and at the end of a sentence. It is sometimes called code-mixing by some linguists where it found a word, a phrase, or a clause of a foreign language within the sentence in a base language (Ganji et al., 2020; Rossi et al., 2021). In summary, all types of code-switching refer to switching back and forth from one language to another to communicate to others based on the situation (Ataş \& Sağın-Şimşek, 2021). Code-switching is a common phenomenon that happens in the level of word, phrase, and clause or sentence depending on their need in speaking. Many previous pieces of research have identified code-switching occurrences in the EFL classroom setting (Chau \& Lee, 2021; Yacovone et al., 2021). Following types of code-switching according to Poplack's theory which consisted of tag-switching, intra-sentential switching, and inter-sentential switching have been identified.

The findings of previous research stated that both teachers and students employed the three types of code-switching in different contexts of language use, namely: tag switching, inter-sentential switching, and intrasentential switching (Yacovone et al., 2021; Zhu et al., 2021). Moreover, intra-sentential code-switching was mostly used in EFL classroom activities where students frequently uttered intra-sentential switching in their 
group presentation, speech, and daily conversation (Hamed et al., 2022; Kheder \& Kaan, 2021). Accordingly, this present research proposed similar aims to the above-mentioned research, yet this research will be different from those previous researches in some cases. While the research above focused on EFL code-switching in the classroom setting; however, this research is focused on code-switching occurrences in fully online synchronous EFL teaching and learning due to the covid-19 pandemic. Therefore, the context of this present research is fully online EFL learning that is conducted by EFL prospective teachers and the students of Junior and Senior High School through WhatsApp group chat which is applicable for the students in this context. Moreover, the problem identified in this issue of written discussion done by teachers and students through WhatsApp group chat is in the term of language used, specifically code-switching occurrences, particularly the way of delivering the learning materials, giving instruction, and way of communication during the process of learning. Furthermore, there is a reason for choosing the subject of the research, that there has not yet been research found in investigating code-switching in fully online learning using WhatsApp. The purpose of this study is to analyze Code-Switching in Online Synchronous Learning. Considering this phenomenon of teaching and learning process, the present study will explore the types of code-switching produced by the prospective teacher and students through the online teaching and learning has done as well as to discover the function of code-switching utilizes.

\section{METHOD}

The study was designed as descriptive qualitative research. Qualitative data could provide an understanding of social situations and interactions, as well as people's values, perceptions, motivations, and reactions. Furthermore, the subject in this study was six EFL prospective teachers and intermediate and high school students. The primary data was gathered from the online discussion of students' teachers through their WhatsApp group chat and then the discussion was transcribed into a transcript. From the discussion transcript, the process of data identification was done by highlighting each sentence containing tag-switching, intrasentential switching, and inter-sentential switching (i.e.Poplack's theory). Also, the functions of code-switching referred to a theory from Sert. The findings are then supported with results from the previous study as published in research articles in reputable international journals indexed by Scopus and Web of Science, as well as nationally accredited journals ranked in Sinta 1-Sinta 4, published 2010 to 2020 to represent the implementation of code-switching.

\section{RESULT AND DISCUSSION}

\section{Result}

There were six participants in this research who all of them were EFL prospective teachers that conducted their practice teaching in several schools in Bali, specifically Junior High School and Senior High School. The concern of this research was code-switching occurrences of EFL prospective teachers and their students during the online synchronous teaching and learning through WhatsApp group chat. The identification of the code-switching types according to Poplack's theory was divided into three parts, namely: tag-switching, intra-sentential switching, and inter-sentential switching. The first type of code-switching according to Poplack's theory was tag-switching. Tag-switching appeared as the most common type of code-switching that occurred in their online teaching. There were several sentences presented below:

(1) $[09: 33,8 / 24 / 2020]+62$ 821-4709-0902: $O k$ pak ]

[12:32 PM, 9/10/2020] S1: Okay, cek materinya di atas ]

[8:41 pm, 30/09/2020] +62 887-3411-971: yes sir, terlalu bnyk tugas mknya ambil jalan pintas

(2) [10:45 AM, 10/3/2020] +62 878-6319-0744: Sudah miss thank you $囚]$

[04/09/20 09.52.40] Nayla Lareina: Beneh miss? ]

[8/29/20, 13:42 - +62 853-3722-8977: Enggak tau $m s$ ]

[04/09/20 09.57.54] Widi Adnyana: Kto Miss? ]

(3) $[10: 42,10 / 12 / 2020] \mathrm{S} 2:$ Iya dindya that's good answer ß]

[8/29/20, 13:54 - S5: Good, enough ya ]

[9/5/20, 11:49 - S5: Wait $y a]$

(4) [11:06 AM, 9/3/2020] S1: Good job, kalian bisa perhatikan penjelasan yang miss berikan ]

[10:22 AM, 10/3/2020] Ni Wayan S1: Really? Yakin semua sudah paham? ]

From the sentences above, tag-switching was used by the prospective teachers and students in their online discussion, which was commonly used as tag or interjection, such as: well, okay, miss, good job, good, hi, 
and thank you. The second type of code-switching that occurred in this online teaching and learning was intrasentential switching. There were several sentences proposed as intra-sentential switching, for instance:

(1) [10:41 AM, 9/3/2020] S1: Jam 10:30, ada dua cara untuk menyebutkan jam ini dalam Bahasa inggris

1. Ten thirty (ini cara yang sederhana) ]

2. half past ten (biasanya ini yang sering digunakan dalam menyatang jam "setengah ...." misalnya seperti yang kita bahas sekarang yaitu jam setengah sebelas kita bisa ucapkan dengan "half past ten" $=10: 30$. Kenapa ten karena sebelum 11 itu adalah 10 , paham sampa sini?? ]

[10:33, 10/12/2020] S2: Okay that's good desak 3

Tapi ingat pakek "should" ya, Jadinya "you should drink orange juice"]

[13.31, 7/9/2020] S3: Okay good. In Indonesian, it is 'olesi'. Tadi kalian menjawab 'oil', is that true? What do you think the best answer? ]

8/29/20, 14:08 - S5: Good logic. Grammatically, it can be I. But in logically you are right. Jadi bisa menggunakan $I$ atau you. Namun secara grammar tetap pakai $I$ yaa, karna mengikuti formula ]

[5:41 pm, 23/08/2020] S6: Jadi, kita akan mendalami materi tentang exposition analytical, saya akan kasi kalian materi beserta contohnya, jadi disini tugas kalian agak berat (tapi dikit) $?$, saya akan kasi kalian batas waktu yg cukup lama untuk menyelesaikan semua? ]

(2) $[13.31,24 / 8 / 2020]$ S3: Dari tugas yang kakak berikan kemarin, hanya 17 orang yang mengumpul tugasnya. Dari 17 orang hanya 1 yang mendapat nilai 100. I really appreciate it. Sisanya, rata-rata mendapat 80 dan 60. For the rest of the students, who did not submit the task, sorry guys, you got 0 points. ]

8/29/20, 12:07 - S5: Okay, kalau memang tidak ada pertanyaan lagi kita akan akhiri pertemuan hari ini. Untuk materi ini Ms sudah siapkan tugas di Google Classroom. I'll post the task on Google classroom. Look at the due date and instruction, if you have any question about the instruction you can ask it here. ] 8/29/20, 11:45 - S5: I think that's enough. Next, please make 3 sentences using simple past tense (buat bentuk + - dan ?) ]

(3) [10:07 AM, 9/10/2020] S1: No, no, No problem, you did a great job, Sangat bagus sudah mau mencoba. Keep learning]

[10:33 AM, 10/3/2020] +62 821-4419-3900: You are welcome miss Maaf tadi kurang kata $\Omega$ ]

[10:57 AM, 9/3/2020] +62 853-3900-4556: Sy gak tau caranya copy chat miss $\Omega$

[12.51, 31/8/2020] S3: Kakak akan random sekarang. ]

[8/29/20, 11:25 - +62 813-3827-0255: 23 belum join, miss]

[6:52 pm, 11/10/2020] Anggi Murid AP 1: Tidak ada materials kak ]

In the illustration above, intra-sentential switching occurred in students' teacher online discussion through WhatsApp group chat. It was frequently uttered by the teacher during the online discussion through WhatsApp group chat where they were trying to connect both languages used (Indonesian language and English) within the sentence in delivering their intention through online written communication. The third type of codeswitching that occurred in this online synchronous learning through WhatsApp was inter-sentential switching which was in the smallest percentage of occurrences. Further, the example presented as below:

(1) [10:30 AM, 9/12/2020] S1: Please watch the video, and pay attention on it. Silahkan tonton video tersebut, dan cermati video tersebut ]

[5:32 pm, 11/10/2020] S6: have you ever heard or read about procedure text? apakah kalian sudah pernah dengar atau membaca tentang prosedur teks? ]

[12.30, 31/8/2020] S3: I will ask student randomly to answer the question. Kakak akan menunjuk siswa secara random untuk menjawab pertanyaannya. ]

[08/09/20 11.14.22] S4: That's okay. For today, please continue the task. If you find any problems in answering the test, you can ask me. Skrg coba jawab dulu ya soalnya, kalo ada yg kurang dipahami, boleh ditanyakan ]

(2) $[09: 51,9 / 7 / 2020] \mathrm{S} 2$ : Contoh lain :

- We must put the trash in trash bin (kita harus membuang sampah pada tempat sampah) - we must be on time (kita harus tepat waktu) ]

[09:49, 8/24/2020] +62 831-1412-5122: I can use this pen (saya bisa menggunakan pulpen ini) ]

[09:02, 8/27/2020] +62 878-4127-8077: Nama kadek juni amelia No 10 Expressing ability is an expressing used when a person had the ability to do something. We usually use can, could, and be able to. Kemampuan mengekspresikan adalah ekspresi yang digunakan ketika seseorang memiliki kemampuan untuk melakukan sesuatu. Kita biasanya menggunakan can, could, dan be able to ]

[18/08/20 12.00.50] S4: Now it's time to test your understanding. Please open your textbook (buku paket). There is a task in the page 46. Please answer the task and write it down on your note book (buku catatan kalian). I will give you 10 minutes to finish it. If you have done the task, please take a photo of your 
answer and send it to me via personal chat in WhatsApp. Later, we will discuss the answer together. Do you understand? ]

From the illustration of inter-sentential switching above, it can be seen that inter-sentential switching was frequently used by teachers in explaining the material, instruction, and also emphasizing certain topics discussed. In analyzing the function of code-switching in this online teaching-learning, this present study referred to the theory of code-switching function (Sert, 2005). They mentioned that there were three functions of codeswitching in communication; they were topic switch, affective function, and repetitive function. For further illustration of each function presented below:

(1) $[8 / 29 / 20,12: 05$ - S5: Hallo, Aurel. Thanks for the question. Untuk bentuk simple past semua subject menggunakan "did" ya. Kalau "does/do" itu untuk simple present tense]

(2) [13.31, 7/9/2020] S3: Okay good. In Indonesian, it is 'olesi'. Tadi kalian menjawab 'oil', is that true? What do you think the best answer? ]

(3) $[8 / 29 / 20,11: 46$ - S5: Cukup untuk formula yaa, sekarang kita ke contoh. Kita bahas satu orang. Jngn ada yg mengirim sebelum $M s$ bilang next]

(4) [10:05 AM, 9/10/2020] S1: Nice try. Mungkin maksud kamu, "Maybe, they still do another assignment" (Mungkin, meeka masih mengerjakan tugas lainnya)]

(5) [9:50 AM, 10/1/2020] S1: okay good, miss tunggu, semngatt $]$

(6) $[09.18,25 / 8 / 2020] \mathrm{S} 3$ : Silahkan jawab pertanyaan itu ya, dikumpulkan besok di atas meja guru jam 10 pagi paling lambat. Good luck

(7) $[12.30,31 / 8 / 2020] \mathrm{S} 3:$ I will ask student randomly to answer the question. Kakak akan menunjuk siswa secara random untuk menjawab pertanyaannya.]

(8) [08/09/20 11.14.22] S4: That's okay. For today, please continue the task. If you find any problems in answering the test, you can ask me. Skrg coba jawab dulu ya soalnya, kalo ada yg kurang dipahami, boleh ditanyakan (2) ]

From the eighth illustrations presented above, the sentences (1) (2) (3) were referred to as the topic switch. It can be seen from sentences in (1) (2) that functioned for explaining grammar topics while (3) functioned for attracting students' attention toward the instruction given. Next, the function of the sentences in (4) (5) (6) was an effective function in which all of the sentences above showed the teacher's praise, wishes, and intimate, or soften the learning atmosphere. Finally, the sentences in (7) (8) were surely used to clarify the instruction in both languages, English and Indonesian language, and it referred to repetitive function.

\section{Discussion}

Based on the research findings presented above, among the six EFL prospective teachers and their students in online synchronous teaching and learning through WhatsApp group chat showed different percentages of code-switching types occurrences. The types identified according to Poplack were: tag-switching, intra-sentential switching, and inter-sentential switching (Ataş \& Sağın-Şimşek, 2021; Chau \& Lee, 2021). The first type of code-switching was tag-switching (Durani et al., 2012; Wu et al., 2017). It was popularly used by the prospective teacher and students in their online discussion which was commonly used as tag or interjection, such as: well, okay, miss, good job, good, hi, and thank you. It was related to the previous studies which mentioned that tag-switching is easy to use in communication since it is only needed to insert a tag, an exclamation, or an interjection of a different language without violating the grammatical rule of the language (Chau \& Lee, 2021; Durani et al., 2012). Furthermore, the most frequent tag-switching that appeared in this online discussion was a word of miss. It was in accordance with a previous study which mentioned that an interjection in form of a name or phrase happened as a statement on its own and shows a spontaneous response or reaction.

The second type of code-switching was intra-sentential switching. It was mostly uttered by the teacher during the online discussion when they were trying to connect both languages used (Indonesian language and English) within the sentence in delivering their intention through online communication. Some of them appeared in the beginning, in the middle, and at the end of a sentence (Gosselin \& Sabourin, 2021). It referred to previous research which mentioned that this type of code-switching links the switch in both languages use, and further for the placement of intra-sentential switching can be found anywhere (Fernandez et al., 2019; Rossi et al., 2021). Furthermore, the language combination of English and Indonesian language is also found within a word, a phrase, and a clause level in a sentence which is related to the previous research (Khotimah et al., 2019; Zein et al., 2020). Accordingly, this type of code-switching was identical to code-mixing since the interlocutor only needed to insert random words, phrases, or clauses of L2 in their native language. 
Finally, inter-sentential switching was the last type of code-switching. The data of the online discussion' transcript found inter-sentential switching occurred at a clausal and sentential level where the teacher uttered their intention in English and gave its meaning into the Indonesian language to get students' understanding. It occurred to clarify the students' understanding of the teachers' instruction or explanation of the topic in both languages. It required the speakers to have great fluency in both languages (Koban, 2013; Pérez \& Duñabeitia, 2019). And that was why there were no students who did inter-sentential switching as they were not fluent enough in both languages (Gosselin \& Sabourin, 2021; Rossi et al., 2021).

In analyzing the function of code-switching in this online teaching-learning through WhatsApp group chat, this present study referred to the theory of Sert. According to the theory used, there were three functions of code-switching, namely: topic switch, affective function, and repetitive function. Topic switch identified when teachers code-switched to the learners' first language to get students' attention to target knowledge being learned, such as grammar instruction to become the bridge for the students' first and target language in learning (Ataş \& Sağın-Şimşek, 2021; Chau \& Lee, 2021). Second, affective functions, aimed at building solidarity and an intimate atmosphere to help students learn comfortably as well as developing strong rapport between teachers and students. And last, the repetitive function was used to ensure clarity of the instruction, question, and explanation to students (Gosselin \& Sabourin, 2021; Yacovone et al., 2021). It is used to repeat some utterances in both the first and target language to ensure that students understand the target language.

Those three functions of code-switching were found in this online learning. In summary, the example of the sentences of each function according to Sert's theory which was presented in the findings indicated that in this online teaching and learning, teachers brought code-switching as a means to make students understand the learning material better, to create an enjoyable learning environment, and to praise students' achievement during the online learning.

This study offered two impacts for the EFL teachers and students by practicing English in terms of code-switching. First, the students and teachers could practice their English in their communication although it is in the form of written communication. Thus, the students could upgrade their writing skills, especially English. Second, by practicing code-switching using WhatsApp group chat, the teachers could make English words or expression lists which frequently used in their online communication. Therefore, the EFL teachers would be easier in expanding the vocabulary and English expression for students to practice their speaking skills.

This study also proposed suggestions based on the result of the study. This suggestion was intended for English teachers and further researches. In this online learning, English teachers could practice code-switching in their online teaching and learning for further self-practice for students and to keep students understanding for the certain topic discussed. Also, for further researchers who get interested in researching a similar topic as this present study, they can explore more about the purpose of written form in code-switching, specifically in an online discussion to enrich this research.

\section{CONCLUSION}

The first result of research in terms of code-switching types revealed that among the research participants, practiced code-switching in their online teaching and learning through WhatsApp group chat. The discussion provided the three types of code-switching based on Poplack's theory, those were: tag-switching, inter-sentential switching, and intra-sentential switching. Furthermore, tag-switching was frequently used in online discussions through WhatsApp. Then, this research showed the three functions of code-switching according to Sert's theory, whichcovereda topic switch, affective function, and repetitive function.

\section{REFERENCES}

Adedoyin, O. B., \& Soykan, E. (2020). Covid-19 pandemic and online learning: the challenges and opportunities. In Interactive Learning Environments. https://doi.org/10.1080/10494820.2020.1813180

Al-Ajlan, A. (2015). The Comparison between Forward and Backward Chaining. International Journal of Machine Learning and Computing, 5(2), 106-113. https://doi.org/10.7763/ijmlc.2015.v5.492

Amiti, F. (2020). Synchronous and asynchronous E-learning. European Journal of Open Education and ELearning Studies, 5(2), 60-70. https://doi.org/10.46827/ejoe.v5i2.3313

Andrade, M. S., Evans, N. W., \& Hartshorn, K. J. (2014). Linguistic support for non-native English speakers: Higher education practices in the United States. Journal of Student Affairs Research and Practice, 51(2). https://doi.org/10.1515/jsarp-2014-0020.

Ataş, U., \& Sağın-Şimşek, Ç. (2021). Discourse and educational functions of students' and teachers' codeswitching in EFL classrooms in Turkey. Linguistics and Education, 65. 
https://doi.org/10.1016/j.linged.2021.100981

Atmojo, A. E. P., \& Nugroho, A. (2020). EFL classes must go online! Teaching activities and challenges during COVID-19 pandemic in Indonesia. Register Journal, 13(1), 49-76. https://doi.org/10.18326/rgt.v13i1.4976

Calvo, C., López-hortelano, M. G., Carlos, J., Vicente, D. C., Luis, J., Martínez, V., Pediatría, D., De, G., \& Asociación, D. (2020). Recommendations on the clinical management of the COVID-19 infection by the (new coronavirus) SARS-CoV2. Clinical Management of Infection By, 92(4). https://doi.org/10.1016/j.anpede.2020.02.002

Chau, D., \& Lee, C. (2021). "See you soon! ADD OIL AR!": Code-switching for face-work in edu-social Facebook groups. Journal of Pragmatics, 184. https://doi.org/10.1016/j.pragma.2021.07.019

Chen, C.-H., \& Tsai, C.-C. (2021). In-service teachers' conceptions of mobile technology-integrated instruction: Tendency towards student-centered learning. Computers \& Education, 170(1). https://doi.org/10.1016/j.compedu.2021.104224

Chen, Y., Mayall, H. J., York, C. S., \& Smith, T. J. (2019). Parental perception and English Learners' mobileassisted language learning: An ethnographic case study from a technology-based Funds of Knowledge approach. Learning, Culture and Social Interaction, 22. https://doi.org/10.1016/j.1csi.2019.100325

Durani, V., Sullivan, B. J., \& Magliery, T. J. (2012). Simplifying protein expression with ligation-free, traceless and tag-switching plasmids. Protein Expression and Purification, 85(1). https://doi.org/10.1016/j.pep.2012.06.007

Fakhruddin, Z., Amzah, A., \& Nurchalis, N. F. (2019). Technology-Based Teaching Material Development Training for Pre-Service Teachers to Improve Students' Learning Outcomes. NOBEL: Journal of Literature and Language Teaching, 10(1), 87-102. https://doi.org/10.15642/nobel.2019.10.1.87-102

Fernandez, C. B., Litcofsky, K. A., \& Hell, J. G. van. (2019). Neural correlates of intra-sentential code-switching in the auditory modality. Journal of Neurolinguistics, 51. https://doi.org/10.1016/j.jneuroling.2018.10.004

Ganji, S., Dhawan, K., \& Sinha, R. (2020). Novel textual features for language modeling of intra-sentential code-switching data. Computer Speech \& Language, 64. https://doi.org/10.1016/j.csl.2020.101099

Gosselin, L., \& Sabourin, L. (2021). Lexical-semantic processing costs are not inherent to intra-sentential codeswitching: The role of switching habits. Neuropsychologia, 159. https://doi.org/10.1016/j.neuropsychologia.2021.107922

Hamed, I., Denisov, P., Li, C.-Y., \& Elmahdy, M. (2022). Investigations on speech recognition systems for lowresource dialectal Arabic-English code-switching speech. Computer Speech \& Language, 72. https://doi.org/10.1016/j.csl.2021.101278

Hogan, R., \& Devi, M. (2019). A synchronous pedagogy to improve online student success. International Journal of Online Pedagogy and Course Design, 9(3), 61-77. https://doi.org/10.4018/IJOPCD.2019070105

Hsieh, S. H., \& Tseng, T. H. (2017). Playfulness in mobile instant messaging: Examining the influence of emoticons and text messaging on social interaction. Computers in Human Behavior, 69. https://doi.org/10.1016/j.chb.2016.12.052

Huang, X., Dedegikas, C., \& Walls, J. (2011). Using multimedia technology to teach Modern Greek Language online in China: Development, implementation and evaluation. European Journal of Open, Distance and E-Learning, 1, 1-9. https://eric.ed.gov/?id=EJ936382

Ika Febriandari, E. (2019). Penanaman Nilai Karakter Gemar Membaca Berbasis Pembiasaan Dan Keteladanan Terhadap Kemampuan Berbahasa Siswa Sekolah Dasar. AL-MUDARRIS, 2(2), 211. https://doi.org/10.32478/al-mudarris.v2i2.286

Kassim, M., \& Idris, A. (2018). Multimedia Project on Website Development Using Dreamweaver and Publish Domain Among Engineering Students. International E-Journal of Advances in Education, IV(12), 983993.

Kheder, S., \& Kaan, E. (2021). Cognitive control in bilinguals: Proficiency and code-switching both matter. Cognition, 29. https://doi.org/10.1016/j.cognition.2020.104575

Khotimah, K., Widiati, U., Mustofa, M., \& Ubaidillah, M. F. (2019). Autonomous English learning: Teachers' and students' perceptions. Indonesian Journal of Applied Linguistics, 9(2). https://doi.org/10.17509/ijal.v9i2.20234

Kiernan, J. E. (2020). Pedagogical commentary: Teaching through a pandemic. Social Sciences \& Humanities Open, 2(1), 100071. https://doi.org/10.1016/j.ssaho.2020.100071

Kim, G., Kim, S., Park, M., Park, Y., Lee, I., \& Kim, J. (2021). Forensic analysis of instant messaging apps: Decrypting Wickr and private text messaging data. Forensic Science International: Digital Investigation, 37. https://doi.org/10.1016/j.fsidi.2021.301138

Koban, D. (2013). Intra-sentential and Inter-sentential Code-switching in Turkish-English Bilinguals in New York City, U.S. Procedia - Social and Behavioral Sciences, 70. 
https://doi.org/10.1016/j.sbspro.2013.01.173

Lage-Cala, S., Folgueras-Díaza, M. B., Alonso-Hidalgoa, M., García-Menéndezb, D., \& Fernández-Garcíab, F. J. (2020). Investigation of the effectiveness of online learning tools for energy performance certificates preparation. Energy Reports, 6, 609-614. https://doi.org/10.1016/j.egyr.2019.09.034

Laksana, D. N. L., Dasna, I. W., \& Degeng, I. N. S. (2019). The effects of inquiry-based learning and learning styles on primary school students' conceptual understanding in multimedia learning environment. Journal of Baltic Science Education. https://doi.org/10.33225/jbse/19.18.51

López, K. M. J. de, Feilberg, J., Baena, S., Lyons, R., \& Lyons, R. (2021). "So, I told him to look for friends!” Barriers and protecting factors that may facilitate inclusion for children with Language Disorder in everyday social settings: Cross-cultural qualitative interviews with parents. Research in Developmental Disabilities, 115. https://doi.org/10.1016/j.ridd.2021.103963

Marcu, N. A. (2020). Designing Functional ESP (English for Specific Purposes) Courses. Procedia Manufacturing, 46. https://doi.org/10.1016/j.promfg.2020.03.045

Mershad, K., \& Wakim, P. (2018). A Learning Management System Enhanced with Internet of Things Applications. Journal of Education and Learning, 7(3), 23. https://doi.org/10.5539/jel.v7n3p23

Pérez, A., \& Duñabeitia, J. A. (2019). Speech perception in bilingual contexts: Neuropsychological impact of mixing languages at the inter-sentential level. Journal of Neurolinguistics, 51. https://doi.org/10.1016/j.jneuroling.2019.04.002

Ran, W., \& Jinglu, L. (2020). The Design and Development of Digital Books for E-learning. 2020 4th International Conference on Artificial Intelligence and Virtual Reality, 51-55. https://doi.org/10.1145/3439133.3439140

Rhim, H. C., \& Han, H. (2020). Teaching online: foundational concepts of online learning and practical guidelines. Korean Journal of Medical Education, 32(3), 175-183. https://doi.org/10.3946/kjme.2020.171

Rossi, E., Dussias, P. E., Diaz, M., Hell, J. G. van, \& Newman, S. (2021). Neural signatures of inhibitory control in intra-sentential code-switching: Evidence from fMRI. Journal of Neurolinguistics, 57. https://doi.org/10.1016/j.jneuroling.2020.100938

Sari, I., Sinaga, P., Hernani, \& Solfarina. (2020). Chemistry Learning via Distance Learning during the Covid-19 Pandemic. TADRIS (Journal of Education and Teacher Training), 5(1). https://doi.org/10.24042/tadris.v5i1.6346

Setiawan, I. M. D., \& Ari Oka, I. D. G. (2020). The Use of Audio-Visual Assisted Google Classroom for Mathematics Course. Journal of Education Technology, 4(3), 244. https://doi.org/10.23887/jet.v4i3.28529

Soleimani, E., Ismail, K., \& Mustaffa, R. (2014). The Acceptance of Mobile Assisted Language Learning (MALL) among Post Graduate ESL Students in UKM. Procedia - Social and Behavioral Sciences, 118. https://doi.org/10.1016/j.sbspro.2014.02.062

Wu, T., Fu, F., Zhang, Y., \& Wang, L. (2017). Adaptive tag switching reinforces the coevolution of contingent cooperation and tag diversity. Journal of Theoretical Biology, 330. https://doi.org/10.1016/j.jtbi.2013.04.007

Yacovone, A., Moya, E., \& Snedeker, J. (2021). Unexpected words or unexpected languages? Two ERP effects of code-switching in naturalistic discourse. Cognition, 215. https://doi.org/10.1016/j.cognition.2021.104814

Yaw, Z., Zhou, W., Chen, Z., \& Lim, C. W. (2021). Stiffness tuning of a functional-switchable active coding elastic metasurface. International Journal of Mechanical Sciences, 207. https://doi.org/10.1016/j.ijmecsci.2021.106654

$\mathrm{Yu}, \mathrm{Z}$. (2021). The effects of gender, educational level, and personality on online learning outcomes during the COVID-19 pandemic. International Journal of Educational Technology in Higher Education, 18(1), 1-17. https://doi.org/10.1186/s41239-021-00252-3

Yuan, C.-H., \& Wu, Y. J. (2020). Mobile instant messaging or face-to-face? Group interactions in cooperative simulations. Computers in Human Behavior, 113. https://doi.org/10.1016/j.chb.2020.106508

Zarkasi, Z., \& Taufik, A. (2019). Implementasi Pembelajaran Fikih Berbasis Multimedia Interaktif MacroEnabled untuk Meningkatkan Keaktifan Siswa. SYAMIL: Jurnal Pendidikan Agama Islam (Journal of Islamic Education), 7(2), 169-188. https://doi.org/10.21093/sy.v7i2.1787

Zein, S., Sukyadi, D., Hamied, F. A., \& Lengkanawati, N. S. (2020). English language education in Indonesia: A review of research (2011-2019). Language Teaching, 53(4), 491-523. https://doi.org/10.1017/S0261444820000208

Zhu, X., Lou, Y., Deng, H., \& Ji, D. (2021). Leveraging bilingual-view parallel translation for code-switched emotion detection with adversarial dual-channel encoder. Knowledge-Based Systems, 1. https://doi.org/10.1016/j.knosys.2021.107436 